\title{
Brazil's National Parks
}

\section{Maria Tereza Jorge Padua, Alceo Magnanini and Russell A. Mittermeier}

Brazil is the largest country in South America in both population and area, and ranks fifth largest in the world at $8,511,965 \mathrm{~km}^{2}$. Lying mainly in the tropics, its immense variety of habitat types ranges from the vast, luxuriant Amazon rain forests in the north to the Atlantic coastal forests in the east, the savannas of the central plateau and the Brazilian pine forests and flat, almost treeless pampas of the south; its great diversity of animal species includes some found nowhere else in the world.

As in many other countries, many of the most interesting animals have been decimated by man. Forty-two endangered species occur in Brazil, according to the IUCN Red Data Book: 22 mammals, 4 birds, and 16 reptiles and amphibians, 14 of them red sheet (highly endangered) species. The Endangered Species List issued by the Brazilian Conservation Foundation (FBCN) recognizes 45 species as being threatened with extinction (19 mammals, 24 birds, 2 reptiles - see Table 2). Fortunately, Brazilians have begun to realise the importance of their wildlife heritage and are taking steps to ensure its survival. Brazil now has a young and dynamic National Park System, a branch of the Brazilian Forestry Development Institute (Instituto Brasileiro de Desenvolvimento Florestal-IBDF), which is doing important conservation work. Already Brazil has seventeen national parks (Parques Nacionais) of which the first, Itatiaia, was created as far back as 1937 , followed by Iguaçu and Serra dos Orgãos in 1939. In 1959 came Ubajara, Aparados da Serra and Araguaia, followed in 1961 by nine more: Emas, Chapada dos Veadeiros, Caparáo, Sete Quedas, Sete Cidades, São Joaquim, Tijuca (Rio de Janeiro), Braśilia and Monte Pascoal. The most recent are Serra da Bocaina (1971) and Serra da Canastra (1972). Other parks are being planned. Table 1 gives the planned size of each park as proposed in the governmental act establishing it, the effective size in 1972 and the territorial additions planned for the near future. In addition to the parks there are five federal biological reserves (Reservas Biológicas Federais).

\section{NATIONAL PARKS}

\section{Aparados Da Serra}

Created in 1959 and modified somewhat in 1972 , this is the southernmost park, lying in the north-east of the State of Rio Grande do Sul and the south-east of Santa Catarina. Here the southern Brazilian plateau terminates sharply in precipices of up to $500 \mathrm{~m}$., resulting in an impressive panorama of huge vertical rock walls. Many small pools and springs are to be found on the plateau and the forests of Brazilian pine Araucaria angustifolia here mark the south-eastern limit of this pine's distribution. The lower parts of the park are covered by Atlantic coastal forest. 


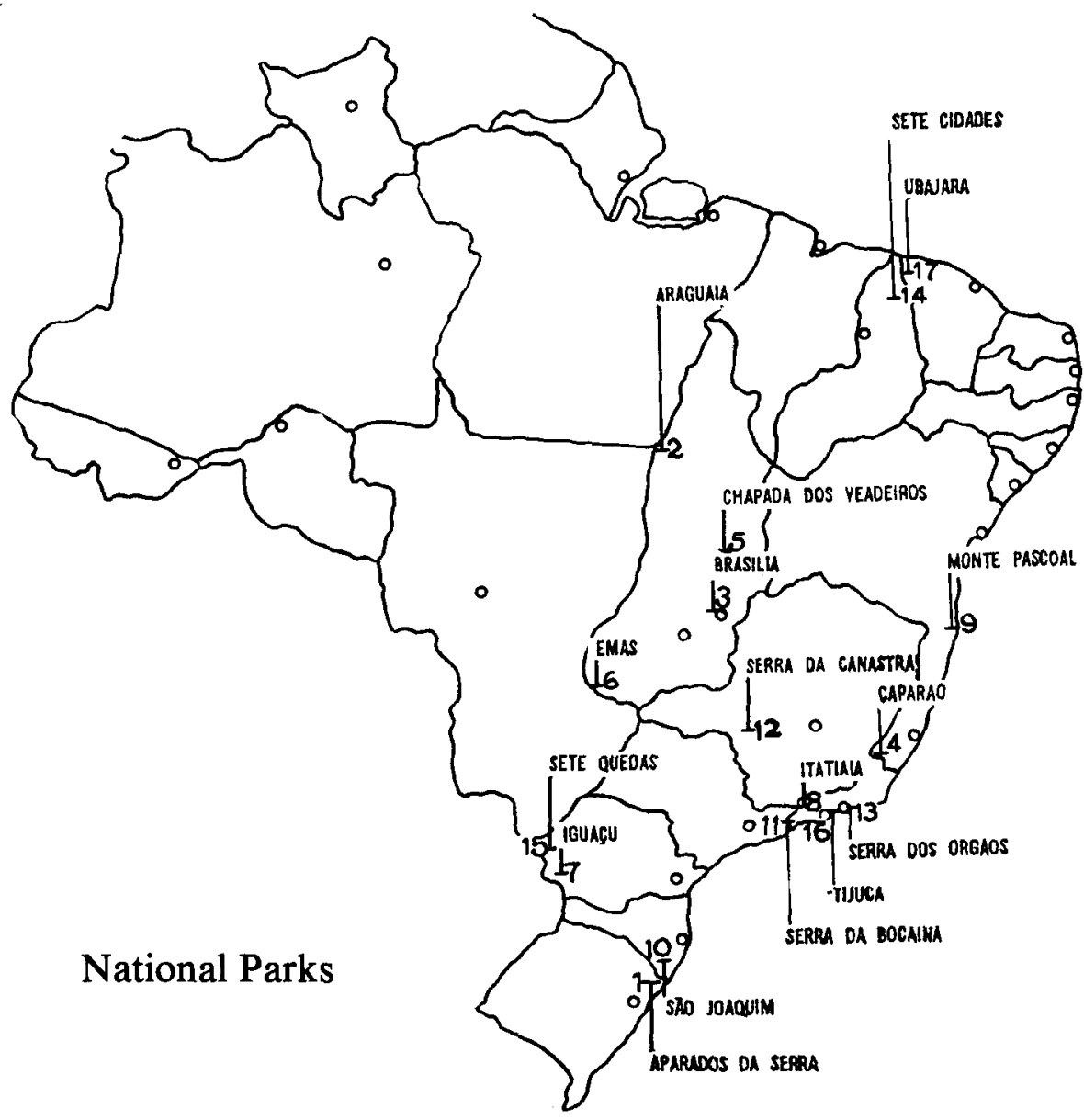

The southern coastal fauna of Santa Catarina finds refuge in the valleys, while the plateau species are well protected in the higher parts of the park. The transition from plateau to lowlands presents an ecotone in which rare and endemic species occur, and the park is a last refuge for local species from the drastic development surrounding the park. Endangered species in the park include pampas deer Ozotoceros bezoarticus, giant anteater Myrmecophaga tridactyla, and giant armadillo Priodontes giganteus.

The park's main tourist attraction is the Canyon of Itaimbezinho, with 400-metre-high waterfalls, and tourist facilities. There is an excellent road from Pôrto Alegre to Sao Francisco $(126 \mathrm{~km})$, from where it is $60 \mathrm{~km}$ by good road to the park gates. The postal address of the park administration is: Rua Coronel Vicente, no. 421-1 andar, Porto Alegre, Rio Grande do Sul.

\section{Araguaia}

Established in 1959 and modified in 1971, Araguaia is in the central western portion of Goias State and includes part of the 2,000,000hectare island of Bananal, the largest fluvial island in the world. The 
main park land, situated between the main stream of the Rio Araguaia and a smaller branch, is flat, composed of quaternary fluvial sediments and covered with numerous lakes and flooded plains, with gallery forest along the rivers and a large forested area at the northern end. Araguaia is in the transition zone between Amazonian forest and the savanna-like 'cerrados'.

Endangered species there include giant anteater, maned wolf Chrysocyon brachyurus, bush dog Speothos venaticus, giant otter Pteroneura brasiliensis, marsh deer Blastocerus dichotomus, pampas deer, and harpy eagle Harpia harpyja.

The major tourist areas are outside the park in the central and southern parts of Bananal Island. The provisional headquarters of the park is at Macaúbas, where there is an airstrip and a port for small boats. Postal address: Praça Cívica no. $10-4^{\circ}$ andar, Goiânia, Goiás.

\section{Brasília}

Created in 1961 in the north-east part of the Federal District of Brazil, the terrain of this park is primarily smoothly rolling high plateau. Plans are under way to add 10,000 hectares in the northeast which would take in Pico do Rodeador $(1341 \mathrm{~m}$.), the highest point in the Federal District, and also deep valleys and many caves and waterfalls. Numerous springs that supply drinking water for the capital city are within the park. The vegetation is predominantly cerrado, with ciliary forests in the vicinity of the springs.

The fauna, which is typical of the central Brazilian plateau, includes several endangered species: giant otter, giant armadillo, maned wolf, bush dog, giant anteater, pampas deer, large-billed seedfinch Oryzoborus crassirostris, and lesser seed-finch $O$. angolensis.

This park is very popular both among residents of the capital, Brasilia, from which it can be reached in fifteen minutes, and visitors from other parts of the country. Postal address: Caixa Postal, 2730, (12)-Brasilia-DF.

\section{Caparaó}

Established in 1961 in the east of the State of Minas Gerais and the south-east of Espírito Santo, the terrain of this park is mountainous and includes the northernmost edge of the Serra do Mar range. Elevations of over 2500 metres are not uncommon, the highest point being the Pico de Bandeira $(2890 \mathrm{~m}$.).

The Espirito Santo part of the peak is entirely tropical rain forest thanks to the rain-bearing winds from the Atlantic, with several different vegetational levels on the west side, tropical forest up to $1800 \mathrm{~m}$., low trees and associations of various smaller plants between 1800 and $2400 \mathrm{~m}$., and above $2400 \mathrm{~m}$. little more than bare ground between rocky outcrops.

The fauna is typical of high-altitude Atlantic coastal forest and endangered species include: buff-headed marmoset Callithrix jacchus flaviceps, giant armadillo, maned wolf, pampas deer and giant anteater. Tourists are few, but numbers are beginning to increase. To the east is the Rio-Bahía Highway, and to the 
north the road linking Manhumirim and the state capital Vitória. Postal address: Rua Silviano Brandão s/n ${ }^{\circ}$, Caixa Postal no. 17. Presidente Soares, Minas Gerais.

\section{Chapada dos Veadeiros}

Created in 1961 in the centre of the State of Goiás, this park is still only in the planning stages, and the area will probably be reduced by some 170,000 hectares because of internal problems and habitat destruction by cattle ranchers. The Chapada dos Veadeiros plateau in the park is quite level and the vegetation typical of the savanna (cerrado) of central Brazil, with gallery forests and strips of dense forest in the most humid areas. Red Data Book species include giant armadillo, maned wolf, bush dog, giant otter, giant anteater, pampas deer, marsh deer, and dwarf tinamou Taoniscus nanus.

Isolated and difficult of access as it is-eleven hours by dirt road from Brasilia - this park has few visitors. Postal address: Edificio do Ministério de Agricultura, Praça Cívica no, $10,4^{\circ}$ andar, Goiânia, Goiás.

\section{Emas}

On the border between south-eastern Goiás and eastern Mato Grosso, this park was created in 1961 and modified in 1972. The gently rolling terrain is typical of the central Brazilian plateau, the vegetation predominantly cerrado, with gallery forests along the rivers. The fauna, typical of the cerrados of central Brazil, includes several endangered species: giant armadillo, giant otter, maned wolf, giant anteater and marsh and pampas deer. Isolated and difficult to get to, there is little tourism at Emas - the choice is between a small plane from Goiânia, capital of Goiás, to Parna, or an unpaved road $650 \mathrm{~km}$ from Brasilia via Rio Verde, Jatái and Serranópolis. Postal address: Edificio do Ministério da Agricultura, Praça Cívica no. 10, $4^{\circ}$ andar, Goiânia, Goiás.

\section{Iguaçu}

The highlight of this park, created in 1939 in the south-east of Paraná, near the confluence of the Rio Iguaçu and the Rio Paraná, is the mile-wide stretch of numerous, thundering waterfalls where the Rio Iguaçu drops off the steep edge of the southern Brazilian plateau - undoubtedly one of the most impressive natural scenic attractions in the Americas. It is contiguous with the Argentinian park of the same name.

The park is covered with humid subtropical forest almost as luxuriant as that of the Amazon region, and rich in tree ferns Cyatheaceae and epiphytes, with two palms, Euterpe edulis and Cocos romanzoffiana, especially abundant. Stands of Brazilian pine Araucaria angustifolia, associated with numerous palms and Phoebe, are limited to a small section in the north-east of the park.

Iguaçu is the largest forest reserve in south-east Brazil and provides protection for many animal species. The endangered ones include giant otter, La Plata otter Lutra platensis, giant anteater, pampas deer, solitary tinamou Tinamus solitarius, harpy eagle, 
ornate hawk-eagle Spizaetus ornatus, black-fronted piping guan Pipile jacutinga, glaucous macaw Anodorhynchus glaucus, vinaceous-breasted parrot Amazona vinacea, and red-spectacled parrot Amazona petrei.

Tourists from all over the world come to Iguaçu to see the famous falls, and the park has an excellent hotel, a museum and various other facilities. In addition, there are numerous hotels and motels in the nearby town of Foz do Iguaçu and on the road between it and the park. Access is by commercial plane from São Paulo or by excellent highway from Curitiba, capital of the State of Paraná. Postal address: Parque National de Iguaçu, Foz de Iguaçu, Estado do Paraná.

\section{Itatiaia}

The first of Brazil's national parks, established in 1937, Itatiaia is in the north of Rio de Janeiro State and south-east of Minas Gerais. The terrain is mountainous and includes the Serra de Mantiqueira Plateau $(2200 \mathrm{~m}$.), renowned for its giant boulders, mostly of volcanic origin, formed in the Jurassic. The highest point in the park is the $2787 \mathrm{~m}$. Pico de Itatiaiuçu. The vegetation consists of tropical rain forest on the higher valleys, and above 1800 metres the typical sparse high-altitude flora.

The montane fauna of the Atlantic belt is well protected in Itatiaia. Red Data Book species include woolly spider monkey Brachyteles arachnoides, maned wolf, La Plata otter, giant anteater, three-toed sloth Bradypus torquatus, solitary tinamou, black hawkeagle Spizaetus tyrannus, harpy eagle, black-fronted piping guan and red-capped parrot Pionopsitta pileata.

Itatiaia has many visitors, especially in holiday months (July and December to March) and at weekends. The park has sleeping facilities and there are many hotels and restaurants outside and in nearby towns. Postal address: Parque Nacional do Itatiaia, Rezende, Estado do Rio de Janeiro.

\section{Monte Pascoal}

This park in the south of Bahia State, established in 1961, takes its name from the isolated peak of Monte Pascoal $(586 \mathrm{~m}$.), the first land sighted in 1500 by the Portuguese mariners who discovered Brazil. Tropical rain forest covers almost the entire park, except for the eight kilometres of beach, with sandstone and conglomerate reefs, dunes, sandbanks and lakes, and some former agricultural plots that are in the process of regenerating. Shoreline vegetation is found on approximately 400 hectares. The tree called 'pau Brasil' Caesalpina echinata, from which Brazil takes its name, occurs in Monte Pascoal.

The fauna is typical of the once forested southern part of Bahia, with Red Data Book species including woolly spider monkey, giant armadillo, giant otter, thin-spined porcupine Chaetomys subspinosus, three-toed sloth, solitary tinamou, black and ornate hawk eagles, red-billed curassow Crax blumenbachii, black-footed piping 


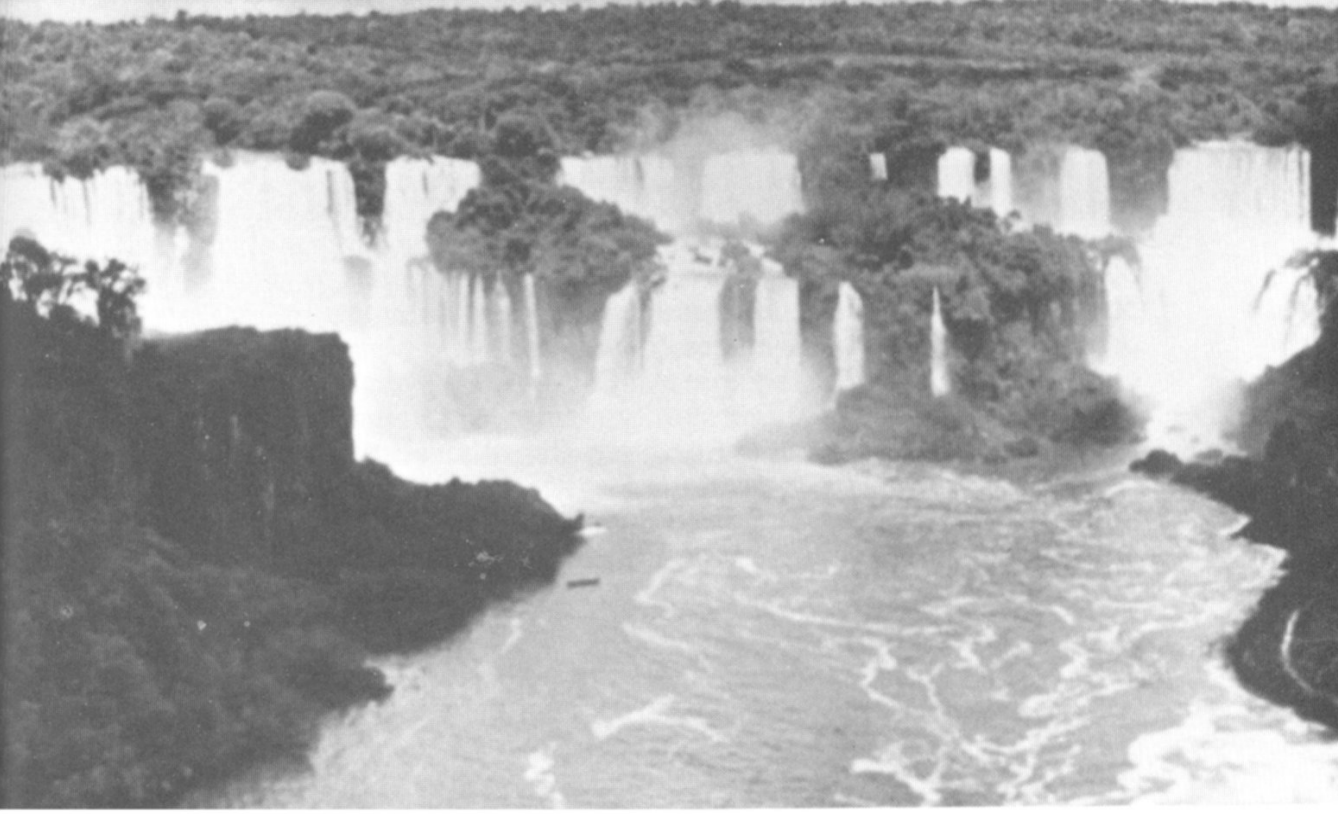

IGUACU FALLS- part of the mile-wide stretch of falls Richard Fitter

guan, large-billed and lesser seed-finches, and red-browed parrot Amazona rhodocorytha.

There is little tourism in Monte Pascoal, but it can be reached by plane-the park has two small airstrips-by road via Montinho, from which it is only $11 \mathrm{~km}$ - or boat from Porto Seguro to Ponta de Caraíva and Cabo de Corumbau. Postal address: Edificio Suerdick, Avenida Estado Unidos, $14-4^{\circ}$ andar, ss/405/409,

Salvador, Bahia.

\section{Sao Joaquim}

Created in 1961 in the south-east of Santa Catarina State, this park is still in the process of being established. In the future, it will be renamed Pedra Furada. It lies on the southern Brazilian plateau and every winter gets several days of snowfall, something quite unusual in tropical Brazil. The plateau is cut by numerous deep valleys in the bottoms of which are subtropical forests, with ciliary pine forests higher up. The top of the plateau is predominantly savanna. The fauna is typical of the southern plateau, mixed with forest species in the valleys. Address: Caixa Postal, 395, Florianópolis, Santa Catarina.

\section{Serra da Bocaina}

Created in 1971 in the south-east of Rio de Janeiro State and the north-east of Săo Paulo, this park is in the process of being established. It includes an island in the ocean, a cove and sandy and rocky beaches. In the northern part there are deep valleys that cut 
into the Serra da Bocaina plateau, and a section of plateau above 1800 metres that is marked by gigantic rounded granite masses. Tropical rain forest predominates up to 1800 metres, above which it is replaced by plains and gallery forests of Araucaria angustifolia and Podocarpus species.

The fauna of the forested Atlantic slopes is protected in this park, as are species endemic to the grasslands and pine forests of the high plateau. Endangered species include woolly spider monkey, giant otter, La Plata otter, giant anteater, solitary tinamou, harpy eagle, ornate and black hawk-eagles, black-fronted piping guan and redcapped parrot.

This new park will probably become an important tourist attraction, since it is located between Brazil's two largest cities, Rio de Janeiro and São Paulo, and the new Rio-Santos highway will pass by it. Address: Delegacia Estadual do Rio de Janeiro, Alameda Sao Boaventura, 904, Fonseca-Niteroi.

\section{Serra da Canastra}

The newest park, created in 1972, this covers approximately 200,000 hectares in Minas Gerais. Within its borders are the springs that give rise to the Rio São Francisco, and the forests and highaltitude plains that provide outstanding panoramas.

\section{Serra dos Orgãos}

Created in 1939 in the centre of Rio de Janeiro State, this park takes in the rugged edge of the giant fault block of the Serra dos Orgãos massif, including the famous 'Dedo de Deus' (Finger of God). Typical Atlantic coastal forest predominates up to 1800 metres, then high-altitude forest between huge outcroppings of rock up to 2000 metres and above that mainly grass, bushes and small trees with moss and lichen-covered rocks. The endemic plant Prepusa hookeriana, of the gentian family, which is on the Brazilian Endangered Species List, is found here.

The park has many Atlantic coastal forest species, including woolly spider monkey, La Plata otter, three-toed sloth, solitary tinamou, ornate and black hawk-eagles, and black-fronted piping guan. Only two hours from the city of Rio de Janeiro by excellent highway, and close to the city of Teresópolis, this park is very popular and has many facilities for mountaineers and other tourists. It can also be reached via Petrópolis. Postal address: Parque Nacional da Serra dos Órgãos, Teresópolis, Rio de Janeiro.

\section{Sete Cidades}

Created in 1961, this park consists of a rolling terrain interrupted by unusual and beautiful formations of eroded Cretaceous sandstone, some of them appearing almost man-made. Savanna predominates, interrupted by gallery forests which contain Amazon palms Mauritia vinifera, and north-eastern palms Copernicia cerifera. The only reserve in this park is important for the protection of the northeastern savanna fauna. It is probably the only area where bearded 
bellbird Procnias averano and banded cotinga Cotinga maculata, two Red Data Book species, could be protected. Maned wolf, giant anteater, Brazilian three-banded armadillo Tolypeutes tricinctus, and pampas deer are also there.

Tourism is still minimal, but expected to increase. The park can be reached either from Piri-Piri via the Fortaleza-Terezina highway or via Brasília and Piracuruca. Postal address: Caixa Postal, 80, Bairro do Jóquei, Terezina, Piauí.

\section{Sete Quedas}

The major attraction in this 233-hectare park on the Rio Paraná, between Brazil and Paraguay, are the Falls of Guaira, or Seven Falls from which it takes its name. But its park status will be annulled in the near future, as the falls are to become part of a hydroelectric project. All the surrounding area has already been modified by agriculture and ranching.

\section{Tijuca}

Created in 1961 as the Rio de Janeiro National Park in southeastern Guanabara, this park is almost entirely surrounded by the city of Rio de Janeiro and has within its boundaries the famous statue of Cristo Redentor, Christ the Redeemer. The terrain is mountainous and up to about 1500 was entirely covered by Atlantic coastal forest. Then for nearly 300 years it was used for pasture, and for coffee and sugar-cane plantations, and most of the original forest was destroyed. At the end of the 19th century, a large reforestation programme began and now self-regenerating tropical forest again covers some 95 per cent of the park.

The fauna was typical of Atlantic coastal forest, but many of the interesting species were exterminated during the 300 years of intensive use. Attempts are now being made to reintroduce some of them-see Table 3. Tijuca is also the home of the Lion Marmoset 'Bank' (IUCN Project no. 16-2 and WWF Project no. 793), a lastditch attempt by Brazilian conservationists to save the three highly endangered forms of Leontopithecus rosalia-see page 437 and also Oryx, May 1971.

Many visitors from all over the world come to this park, most of them to see the statue and the spectacular views of Rio, Sugarloaf Mountain (Pão de Açucar) and Guanabata Bay from the park's highest points. There are numerous restaurants and other facilities inside the park. Postal address: Parque Nacional de Tijuca, Rua Pacheco Leão, 2040, Gávea, Guanabara.

\section{Ubajara}

The smallest of Brazil's national parks, covering 5600 ha., this was created in 1959 in the north-east of Ceara State on the sandstone plateau of the Ibiapaba elevations. The terrain is rugged, with impressive limestone caves and precipices-the Ubajara Cave is a great tourist attraction. Savanna predominates on the plateau top with dense forests harbouring many Amazonian species on the steep slopes. Thorn-bush vegetation ('caatinga'), typical of Ceara State, 
takes over at the base of the plateau. The fauna is still poorly known, but the transition zone between forest and 'caatinga' is certain to offer interesting research possibilities.

The park is only six $\mathrm{km}$. from Frexeirinha-Araticum. Postal address: Rua Rufino de Alencar no. 134, Fortaleza, Ceará, Brazil.

\section{FEDERAL BIOLOGICAL RESERVES}

Brazil's five Federal Biological Reserves are protected areas roughly equivalent to National Parks. They are Cara-Cará, Córrego do Veado, Nove Lombardia, Serra Negra and Sooretama.

\section{Cara-Cará}

Comprising some 70,000 hectares on the Bolivian frontier, right in the swampland ('pantanal') of the Mato Grosso, the fauna of this reserve has not yet been studied, but it is known to contain maned wolf, giant and La Plata otters, bush dog, giant armadillo, giant anteater, marsh and pampas deer.

\section{Córrego Do Veado}

Covering roughly 2400 hectares, this reserve protects the fauna of the low-altitude coastal region of northern Espírito Santo. Many endangered species find refuge there from the drastic environmental alterations that are going on in this part of Brazil: three-toed sloth, giant anteater, giant otter, three-spined porcupine, solitary tinamou, harpy eagle, red-billed curassow, black-fronted piping guan, rackettailed coquette Discosura longicauda, banded cotinga, white-winged cotinga Xipholaena atropurpurea, and large-billed and lesser seedfinches. This reserve also has one of the rarest humming-birds in the world Ramphodon dohrni, and species of the unusual invertebrate genus Peripatus, of the primitive arthropod class Onychophora.

\section{Nova Lombardia}

Covering some 4350 hectares in the mountainous Atlantic coastal region of Espirito Santo, this reserve and the Caparáo National Park are the only remaining relatively untouched areas in that part of the State. Red Data Book species include woolly spider monkey, thin-spined porcupine, buff-headed marmoset, red-capped parrot, racket-tailed coquette Colibri delphinae grunwalti, hooded visorbearer Augastes lumachelus, large-billed and lesser seed-finches, solitary tinamou and black-fronted piping guan.

\section{Serra Negra}

This mountainous, forested 'oasis' of 1100 hectares in the thornbush 'caatinga' in Pernambuco State, has not yet been studied zoologically or botanically, but a programme with Recife University to investigate the area is now under way.

\section{Sooretama}

The purpose of this reserve, covering some 24,000 hectares in the north of Espirito Santo, is to protect the fauna of the once heavy forests of this area. Endangered species represented there include 
Table 1

National Parks

1. Aparados da Serra

2. Araguaia

3. Brasília

4. Caparaó

5. Chapada dos Veadeiros

6. Emas

7. Iguaçu

8. Itatiaia

9. Monte Pascoal

10. Săo Joaquim $\dagger$

11. Serra da Bocaina

12. Serra da Canastra $†$

13. Serra dos Órgãos

14. Sete Cidades

15. Sete Quedas ${ }^{\dagger}$

16. Tijuca

17. Ubajara ${ }^{\dagger}$
Size proposed
in original act

13,000 ha
$2,000,000$
30,000

625,000

*

$*$

12,000

22,500

49,300

140,000

200,000

$*$

7,700

*

$*$

4,000

\section{Effective \\ size 1972}

3,550 ha
3,000
28,000
5,000

79,000

134,000

10,000

22,500

**

***

***

5,000

5,051

233

2,700

64
Additions

planned

10,250 ha

460,000

38,000

10,434

171,924

100,000

170,000

11,943

22,500

18,000

100,000

200,000

10,000

6,221

3,300

563

+ Not in the UN List of National Parks and Equivalent Reserves 1973

*__not in original act **__not yet in effect ***__to be annulled

giant anteater, three-toed sloth, giant armadillo, giant otter, thinspined porcupine, solitary tinamou, harpy eagle, black hawk-eagle, red-billed curassow, black-fronted piping guan, racket-tailed coquette, banded and white-winged cotingas, and large-billed and lesser seed-finches.

\section{LITERATURE CITED}

COIMBRA-FILHO, A. F. and A. D. ALDRIGHI (1971) A restauraçao da fauna do Parque Nacional da Tijuca. Publ. Avul. Mus. Nac. 57: 1-30.

JORGE PADUA, M. T., and A. MAGNANINI (1972) Parques Nacionais do Brasil. Ministerio da Agricultura, Instituto Brasileiro de Desenvolvimento Florestal: $1-32$.

MAGNANINI, A. (1972) A conservação da fauna e os Parques Nacionais e reservas equivalentes no Brasil. In: Especies da Fauna Brasileira Ameaçadas de Extinçāo, Academia Brasileira de Ciencias, Rio de Janeiro, 167-175.

MELO CARVALHO, J. C. de (1968) Lista das espécies de animais e plantas ameaçadas de extinca̛o no Brasil. Fundacão Brasileira para a Conservação da Natureza, Rio de Janeiro, 1-5.

The Authors

MARIA TEREZA JORGE PADUA is Director of the Division for the Protection of Nature (Divisão de Proteção da Natureza) of the Department of Investigation and Conservation of Nature (Departamento de Pesquisa e Conservação da Natureza)-IBDF, Rua Pacheco Leão 2040, Gávea, Guanabara, Brazil.

ALCEO MAGNANINI is Director of the Department of Investigation and Conservation of Nature of the Brazilian Forestry Development Institute (Instituto Brasileiro de Desenvolvimento Florestal-IBDF), Rua Pacheco Leao 2040, Gávea, Guanabara, Brazil.

RUSSELL A. MITTERMEIER, Department of Anthropology and Museum of Comparative Zoology, Harvard University, Cambridge, Massachusetts 02138, USA. 


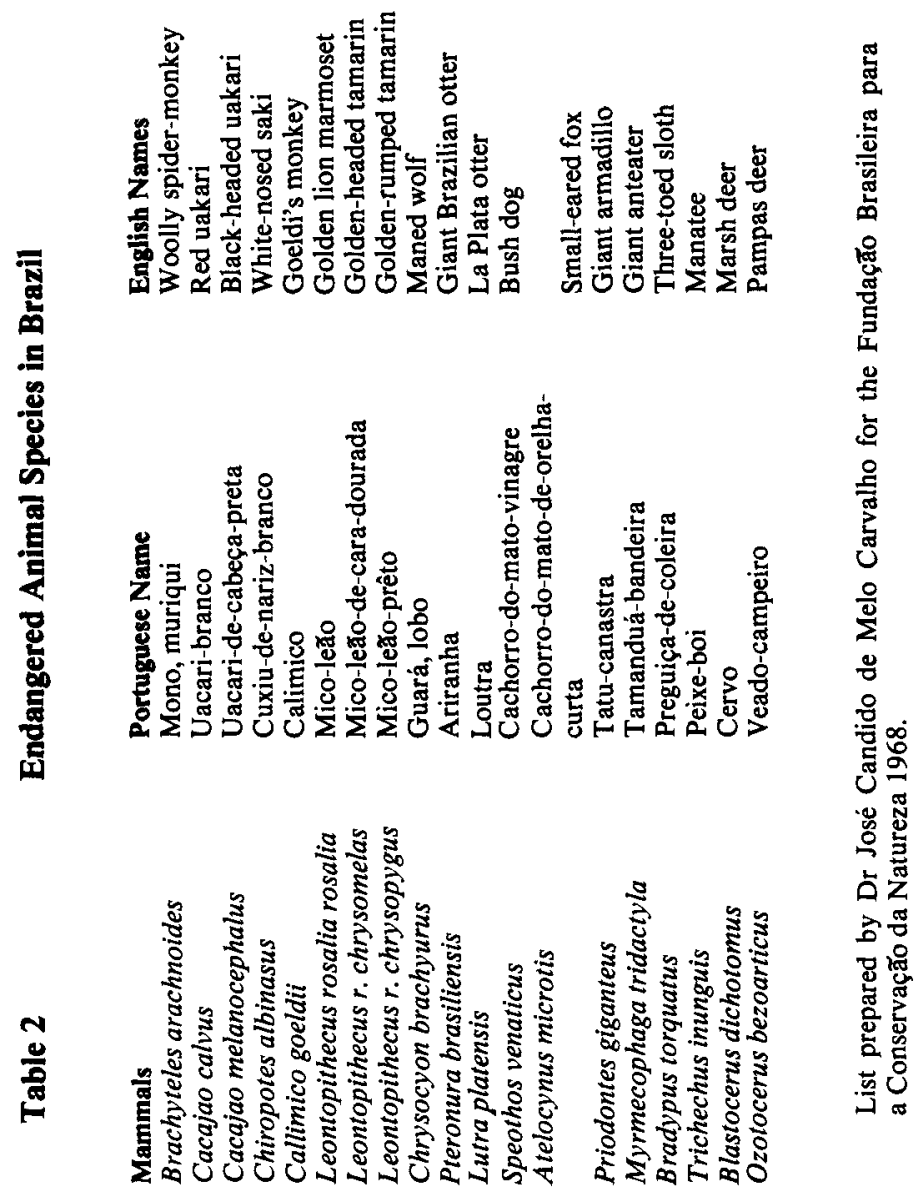



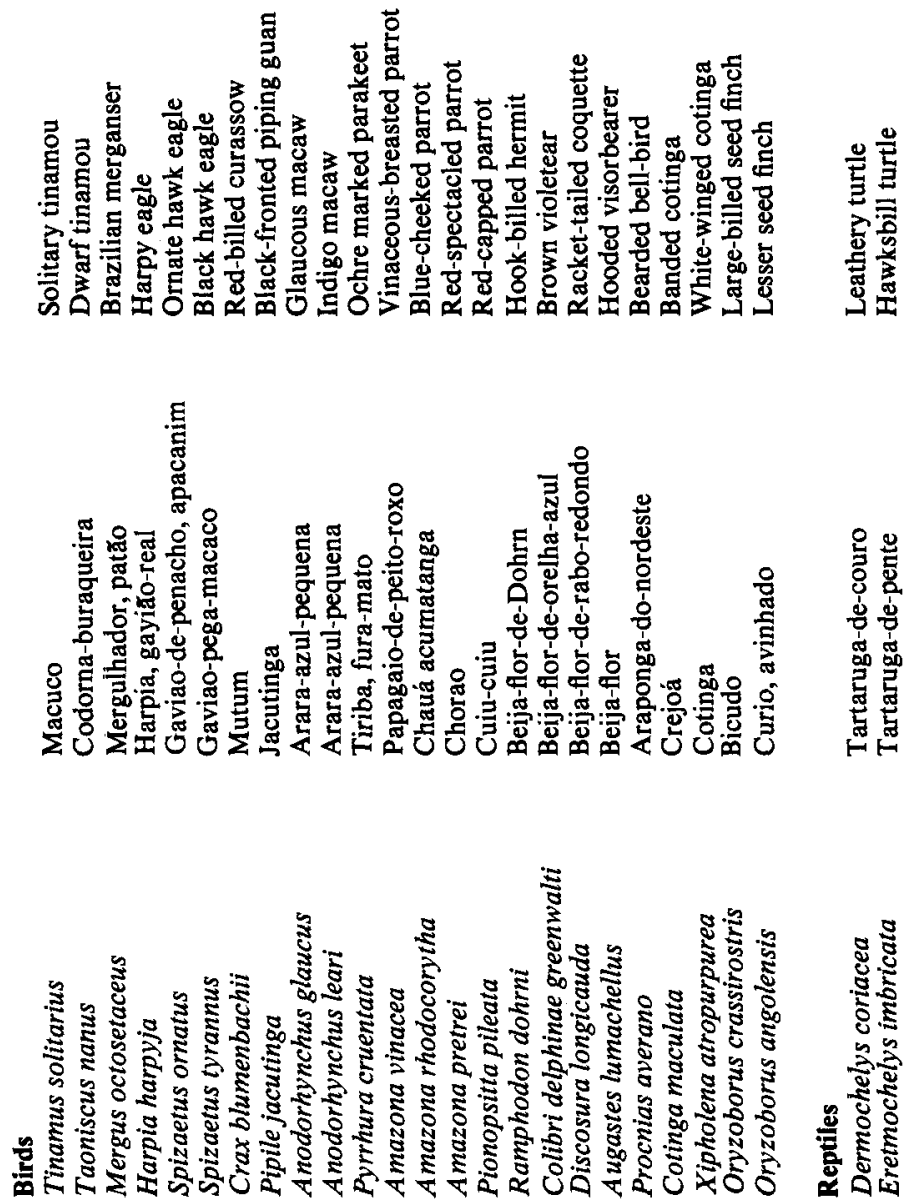
Table 3

\title{
Reintroductions in Tijuca National Park
}

\section{Mammals}

Leontopithecus r, rosalia* Brachyteles arachnoides* Tamandua t. tetradactyla Bradypus infuscatus brasiliensis

Bradypus torquatus*

Dasypus n. novemcinctus

Tayassu t. tajacu

Mazama americana jucunda

Sciurus aestuans ingrami

Dasyprocta a. aguti

Agouti p. paca

\author{
to be reintroduced \\ to be reintroduced \\ 1 male, 1 female \\ 2 males, 3 females \\ 2 males, 1 female, 1 juvenile \\ 1 juvenile \\ to be reintroduced \\ to be reintroduced \\ exists in park (1 male, 1 female) added to \\ population \\ more to be introduced \\ more to be introduced
}

\section{Birds}

Tinamus s. solitarius*

Crypturellus soui albigularis

Crypturellus n. noctivagus

Crypturellus t. tataupa

Penelope superciliaris jacupemba

Pipile jacutinga*

Odontophorus c. capueira

Leptotila rufaxila reichenbachii

Geotrygon m. montana

Pyrrhura cruentata*

Pyrrhuraf. frontalis

Pyrrhura l. leucotis

Brotogeris tirica

Touit melanonota

Pionopsitta pileata*

Piaya cayana macroura

Ramphastus vitellinus ariel

Pteroglossus aracari wiedi

Selenidera m. maculirostris

Baillonius bailloni

Melanerpes flavifrons

Cacicus haemorrhous affinis

Icterus cayanensis tibialis

Saltator s. similis

to be reintroduced

to be reintroduced

to be reintroduced

exists; 16 specimens to be added

exists; 2 specimens to be added

to be reintroduced

8 specimens

exists; 2 specimens to be added

exists; more to be introduced

66 specimens

42 specimens

95 specimens

exists; 3 specimens to be added

exists; more to be introduced

to be introduced

to be reintroduced

46 specimens

to be reintroduced

exists; more to be introduced

26 specimens

3 specimens

39 specimens

24 specimens

50 specimens

* Species in danger of extinction.

Reintroductions were made in 1970 and 1971. Almost all the reintroduced animals were confiscated from pet dealers or removed from areas where habitat destruction was under way. This list is from Coimbra-Filho and Aldrighi, 1971. 